\title{
МОРФОЛОГІЧНІ ЗМІНИ У НИРКАХ ПРИ ЕКСПЕРИМЕНТАЛЬНОМУ АНТИФОСФОЛІПІДНОМУ СИНДРОМІ ТА ЗАСТОСУВАННІ МОДУЛЯТОРІВ СИНТЕЗУ ОКСИДУ АЗОТУ
}

\author{
๑О. 3. Яремчук, 3. М. Небесна, С. Б. Крамар, К. А. Посохова
}

Тернопільський національний медичний університет імені І. Я. Горбачевського МОЗ України

РЕЗЮМЕ. Нирки є одним із основних органів-мішеней при всіх клінічних формах антифосфоліпідного синдрому (АФС).

Мета - оцінити вплив попередника синтезу оксиду азоту L-аргініну та інгібітора індуцибельної NO-синтази аміногуанідину на морфофункціональні зміни у нирках при експериментальному АФС.

Матеріал і методи. Дослідження виконано на мишах-самках лінії BALB/c, в яких моделювали АФС. Для корекції використовували L-аргінін (25 мг/кг) та аміногуанідин (10 мг/кг). Забір матеріалу для мікроскопічних досліджень проводили згідно з загальноприйнятою методикою. Зразки тканини нирок фарбували гематоксиліном i еозином.

Результати. Мікроскопічні дослідження нирок тварин з АФС виявили деструктивні зміни всіх компонентів та порушення мозкового і кіркового кровообігу органа. Гістологічні зміни нирок тварин із модельованим АФС, яким вводили L-аргінін, проявлялися зменшенням кровонаповнення судин органа із збереженням цілісності судинної стінки. Мікроскопічні зміни нирок тварин з АФС, яким вводили аміногуанідин, характеризувалися розширенням і кровонаповненням судин, переважно дрібних артерій кіркової речовини.

При введенні L-аргініну та аміногуанідину за умов АФС у нирках тварин виявлено відновлення судинного компонента органа, залишалися кровонаповненими тільки міжчасткові та міжчасточкові вени.

Висновки. В нирці за умов АФС відбуваються судинні порушення, які призводять до значних деструктивних змін нефронів. Застосування модуляторів синтезу оксиду азоту (L-аргініну та аміногуанідину), окремо та, особливо, при їх комбінованому введенні, приводить до зменшення патологічних змін компонентів нефрона за умов АФС у мишей лінії BALB/c.

КЛючОВІ СЛОВА: антифосфоліпідний синдром; нирки; L-аргінін; аміногуанідин.

Вступ. Антифосфоліпідний синдром (АФС) автоімунне захворювання, що характеризується наявністю в крові антитіл до негативно заряджених фосфоліпідів мембран (аФЛ) [1]. Нирки є одним із основних органів-мішеней при всіх клінічних формах АФС. у більшості випадків при АФС нефропатія поєднується з ураженням центральної нервової системи, серця, судин, або з акушерською патологією [2]. Ураження нирок $\epsilon$ одним із найчастіших проявів катастрофічного АФС, який майже в 50 \% випадків $є$ летальним [3].

Морфологічні зміни, які характеризують васкулопатію при АФС, мають широкий спектр. Відомо, що в патогенезі АФС важливу роль відіграє порушення коагуляції і/або пошкодження ендотелію судин $[4,5]$. Нирковий ендотелій реагує в першу чергу на системну ендотеліальну дисфункцію у хворих з АФС. При цьому спостерігається гіперпродукція судинного ендотеліального фактора росту (VEGF), ендотеліну-1, Е-селектину, пошкодження капілярів клубочків та артеріол нирок [6]. Доведено, що при АФС в ендотелії порушуються синтез та біодоступність оксиду азоту (NO), який бере участь у регуляції судинного тонусу і коагуляційних властивостей крові [7-9].

Утворення тромбів у судинах малого калібру (артерії, артеріоли, гломерулярні капіляри) при
АФС зустрічається частіше, ніж тромбози великих ниркових артерій і вен. Частота інтраренального тромботичного ураження коливається від 25 до 68 \% [2]. Судинні зміни поєднуються з патологією строми і паренхіми різних органів. Розшарування і розрив судин можуть призводити до крововиливів у білу речовину головного мозку, в інтерстицій нирок і строму печінки [4].

Залежно від локалізації тромбозів у судинному руслі нирок, тривалості й швидкості розвитку процесу тромбоутворення, клінічні прояви АФСнефропатії варіюють від гострого пошкодження нирок і тяжкої артеріальної гіпертензії до мінімального сечового синдрому і повільного прогресування порушення функції нирок $[2,10]$. Клінічні прояви, пов'язані з АФС-нефропатією, під час вагітності складно відрізнити від прееклампсії i HELLP-синдрому, які мають загальні прояви 3 АФС-нефропатією - гіпертензія, протеїнурія, тромбоцитопенія. Ураження нирок при АФС $\epsilon$ результатом тромбозів ниркових артерій, внутрішньопаренхіматозних артерій, клубочкових капілярів або ниркових вен з розвитком так званої тромботичної мікроангіопатії внутрішньониркових судин. Це призводить до розвитку ішемії нирок і прогресуючої ниркової недостатності внаслідок наростаючого нефросклерозу [10]. 
Огляди літератури, оригінальні дослідження, погляд на проблему, випадок з практики, короткі повідомлення

Відомо декілька основних механізмів розвитку тромбозу судин при АФС [1, 10-12]: пряма взаємодія між аФЛ і білками, що регулюють фібринолітичні і коагуляційні шляхи, активація ендотеліальних клітин, моноцитів і тромбоцитів за допомогою взаємодії між аФЛ і фосфоліпід-зв'язуючими білками плазми крові, що взаємодіють 3 мембранами і їх рецепторами, активація антитіл до $\beta 2$-глікопротеїну-І ( $\beta 2 Г П І)$. До фосфоліпід-зв'я-

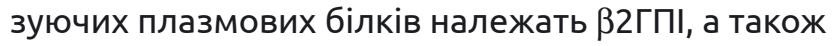
протромбін, тромбомодулін, кініноген, антитромбін III, білок C, білок S, анексин I, II і V $[10,11]$.

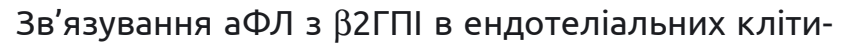
нах, моноцитах і тромбоцитах індукує передачу сигналів, здатних стимулювати прокоагулянтні і прозапальні зміни, експресію молекул адгезії і вивільнення тканинних факторів та інгібіторів фіб-

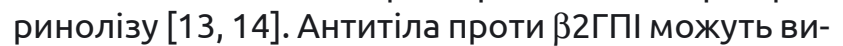
кликати активацію тканинного фактора у моноцитах і ендотеліальних клітинах, який відіграє важливу роль в ініціації зовнішнього коагуляційного каскаду $[10,13]$. Відомо, що аФЛ зв'язуються з активованими факторами згортання, включаючи тромбін, активовані фактори IX і X, запобігаючи їх інактивації і знижуючи фібриноліз. Комплек-

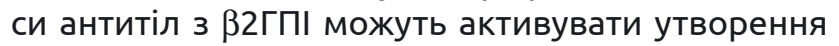
С5а комплементу, який, в свою чергу, індукує розвиток запалення. С5а може активувати нейтрофіли, що призводить до експресії тканинного фактора, який взаємодіє з фактором VIIa, активації фактора X, синтезу тромбіну i, в результаті, до тромбоутворення [1, 10-12].

Незважаючи на існування ряду наукових досліджень щодо АФС-нефропатії та механізмів розвитку тромбозу при АФС, на сьогодні залишаються недостатньо вивченими роль системи оксиду азоту у механізмах ураження нирок та ремоделювання їх структурних компонентів за умов АФС.

Мета - оцінити вплив попередника синтезу оксиду азоту L-аргініну та інгібітора індуцибельної NO-синтази аміногуанідину на морфофункціональні зміни у нирках при експериментальному антифосфоліпідному синдромі.

Матеріал і методи дослідження. Дослідження проводили на 50 мишах-самках лінії BALB/c, яких утримували на стандартному раціоні віварію. Експерименти здійснювали з дотриманням принципів біоетики відповідно до «Загальних етичних принципів експериментів на тваринах» (Київ, 2001) узгоджених з положеннями «Європейської конвенції щодо захисту хребетних тварин, що використовуються в експериментальних та інших наукових цілях» (Страсбург, 1986) та Директиви Європейського Союзу 2010/10/63 EU щодо експериментів на тваринах.
АФС моделювали за допомогою кардіоліпіну ("Sigma», USA), який вводили внутрішньом'язово, чотири рази (30 мкг на 1 ін'єкцію, проміжки між ін'єкціями становили 14 діб) [15]. Для підвищення ефективності імунної відповіді кардіоліпін емульгували в 75 мкл повного ад'юванту Фрейнда (перша ін'єкція), наступні ін'єкції проводили з неповним ад'ювантом Фрейнда. Піддослідних тварин поділили на 5 груп: 1 - інтактні; 2 - миші з АФС; 3 - тварини з АФС, яким вводили L-аргінін ("Sigma», USA, 25 мг/кг), 4 - тварини з АФС, яким вводили аміногуанідин («Хімлабораторреактив", Україна, 10 мг/кг), 5 - тварини з АФС, яким вводили L-аргінін у комбінації з аміногуанідином. L-аргінін та аміногуанідин вводили внутрішньоочеревинно один раз на день упродовж 10 діб після формування АФС. Тварини контрольної групи отримували внутрішньоочеревинно ідентичні об' $\epsilon$ ми розчинника. Через 10 діб з моменту підтвердження АФС тварин виводили з експерименту в умовах тіопентал-натрієвого наркозу (50 мг/кг маси тварини).

Забір матеріалу для мікроскопічних досліджень проводили згідно з загальноприйнятою методикою [16]. Шматочки нирок фіксували в 10 \% нейтральному розчині формаліну, проводили дегідратацію в спиртах зростаючої концентрації, заливали у парафінові блоки. Виготовлені зрізи товщиною 5-6 мкм, забарвлювали гематоксиліном і еозином [16]. Гістологічні препарати вивчали за допомогою світлового мікроскопа MIKROmed SEO SCAN та фотодокументували за допомогою відеокамери Vision CCD Cameга з системою виводу зображення гістологічних препаратів.

Результати й обговорення. Вивчення морфологічних змін у різних органах при АФС продемонструвало розвиток ізольованих тромбозів у мікроциркуляторному руслі під час відсутності тромбозів великих артеріальних або венозних судин при цій патології. В основі нефропатії при АФС лежить тромботична мікроангіопатія, що являє собою особливий тип ураження судин мікроциркуляторного русла різних органів - утворення тромбів, що містять фібрин і агреговані тромбоцити, в артеріях малого калібру, артеріолах і капілярах за відсутності ознак запалення судинної стінки. У нирках найчастіше вражаються капіляри клубочків, артеріоли і міжчасточкові артерії [2].

Проведені гістологічні дослідження нирок тварин інтактної групи встановили загальні закономірності структурної організації органа.

Мікроскопічні дослідження нирок експериментальних тварин, яким моделювали АФС, виявили деструктивні зміни всіх компонентів та порушення мозкового і кіркового кровообігу органа. Визначається розширення просвітів та кровонаповнення 
Огляди літератури, оригінальні дослідження, погляд на проблему, випадок з практики, короткі повідомлення вен та артерій, особливо дрібного калібру, у артеріолах та перитубулярних гемокапілярах і клубочках ниркових тілець виявлялися застійні явища, сладжування еритроцитів, стази. Стінки судин стоншені, деструктивно змінені, спостерігаються кровивиливи. Набряк строми помірний, наявна лейкоцитарна інфільтрація (рис. 1).

Більшість ниркових тілець гіпертрофовані, в них виявляється кровонаповнення судинних клубочків, за рахунок чого значно звужуються просвіти двостінної капсули Шумлянського-Боумена. Також спостерігаються ниркові тільця зміненої форми або зменшені в розмірах, як прояв їх деструкції та гіпотрофії.

Зміни визначаються також і в епітеліоцитах канальців нефрона. Для проксимальних - характерне звуження або нечіткість просвіту, погано контуруються мембрани плазмолеми, наявний набряк, просвітлення цитоплазми клітин, були наявні оптично порожні вакуолі, що свідчить про вогнищевий розвиток гідропічної дистрофії. Подекуди визначалася десквамація нефроцитів у просвіт канальця. В частині епітеліоцитів цитоплазма зерниста або вакуолізована, дистрофічно змінена, їх ядра гіперхромні, пікнотично змінені. Дистальні канальці помірно розширені, епітелій набряклий (рис. 2).

При морфологічному дослідженні нирок у хворих з АФС виявляють незапальну оклюзію ниркових судин як на рівні капілярів, так і на рівні великих артерій і вен. У просвіті судин виявляють тромби, що викликають потовщення інтими, субендотеліальний фіброз і гіперплазію середнього шару судини. Іноді можна бачити атрофію кіркового шару нирок у поєднанні з інтерстиціальним фіброзом, що, ймовірно, є віддзеркаленням ішемії тка-

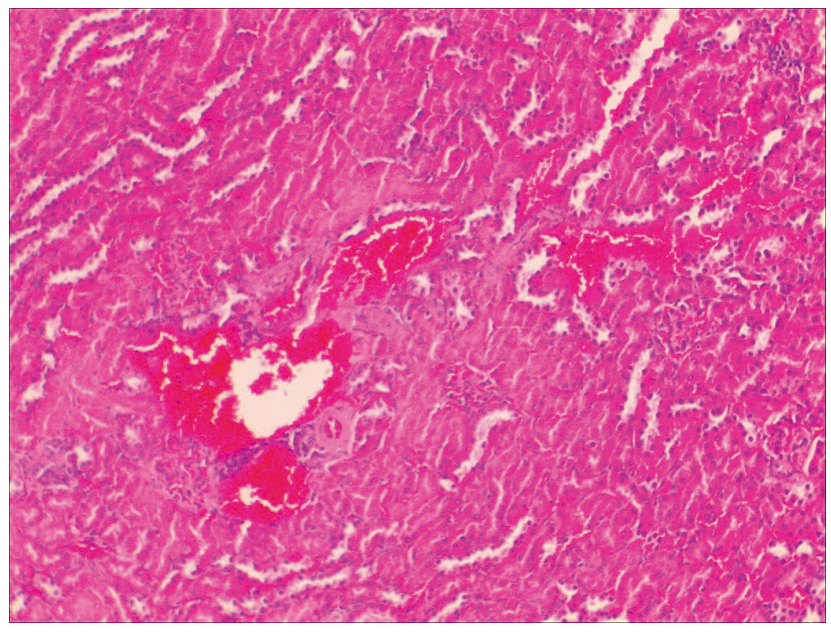

Рис. 1. Мікроскопічні зміни нирки миші лінії BALB/c за умов АФС. Розширені, кровонаповнені просвіти судин, звуження просвіту окремих канальців та дистрофічні зміни епітелію звивистих канальців. Забарвлення гематоксиліном та еозином. × 100. нин [4]. Порушення функції нефроендотеліоцитів підсилює продукцію ренального фактора Віллебранда, молекул клітинної адгезії і тромбомодуліну. Ендотеліальна дисфункція (ЕД) супроводжується дисбалансом активних судинних медіаторів, відповідальних за підтримання нормального тонусу судин, зміною антитромбогенної активності судинної стінки. Пошкодження стінки капілярів клубочків збільшує проходження макромолекул через мезангій, а підвищений синтез вазоконстрикторів (ЕT-1, ТхА2) сприяє експресії широкого спектра факторів росту, активуються ниркові фібробласти, накопичуються компоненти позаниркового матриксу і розвивається нефросклероз [6].

Встановлено сильну кореляцію між наявністю аФЛ і розвитком нефропатії. Вовчаковий антикоагулянт (BA) вважають антитілом, найтісніше пов'язаним з АФС-нефропатією; також є дані про тісний кореляційний зв'язок АФС-нефропатії з антикардіоліпіновими антитілами (аКЛ). Більше того, частота ураження нирок значно вища у пацієнтів з подвійною чи потрійною позитивністю по аФЛ. Висока поширеність АФС-нефропатії спостерігалася у пацієнтів, позитивних по ВА і аКЛ IgG [10]. Одночасно Н. Zheng і співавт. (2009) дійшли до висновку, що у пацієнтів з позитивними антитілами до ВА і

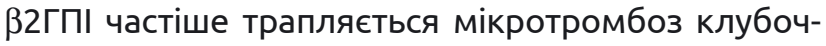

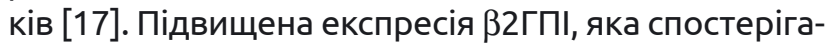
ється в ниркових ендотеліальних клітинах пацієнтів з вовчаковим нефритом, відіграє роль у розвитку АФС-нефропатії $[10,14]$.

Гістопатологічна картина АФС-нефропатії при нефробіопсії характеризується наявністю фібринових тромбів у клубочках і внутрішньонирковій судинній системі за відсутності запальних клітин.

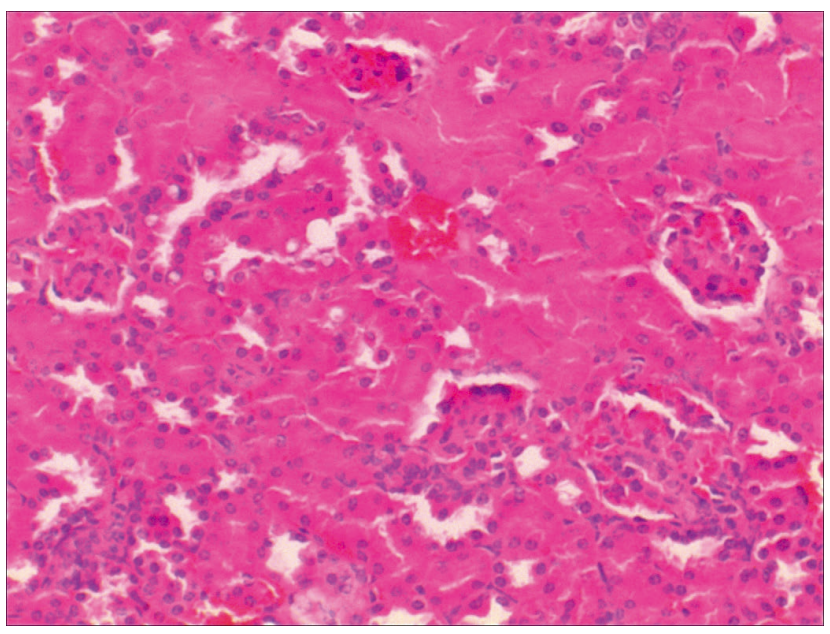

Рис. 2. Мікроскопічні зміни нирки миші лінії BALB/c за умов АФС. Дистрофічно змінений нефротелій канальців нефрона, деформовані гіпер- та атрофічно змінені ниркові тільця, кровонаповнені судини. Забарвлення гематоксиліном та еозином. $\times 200$. 
Огляди літератури, оригінальні дослідження, погляд на проблему, випадок з практики, короткі повідомлення Гострі ураження проявляються тромботичною мікроангіопатією, тоді як хронічні - у вигляді артеріосклерозу артерій і артеріол, фіброзної гіперплазії інтими, фіброзної облітерації артерій і артеріол та фокальної кортикальної атрофії. Фіброзна гіперплазія інтими характеризується інтенсивною продукцією міофібробластів, що призводить до потовщення інтими і звивистості міжлобулярних артерій. Фокальна кортикальна атрофія вражає ділянки на поверхні субкапсулярної кори з невеликими склеротичними або псевдокістозними клубочками, асоційованими з канальцевою атрофією. Фокальний сегментарний гломерулосклероз $є$ характерною ознакою пізньої стадії АФС-нефропатії $[10,18]$. Взаємозв'язок тромботичної мікроангіопатії з наявністю аФЛ при АФС має важливе терапевтичне значення і дозволяє відрізнити АФС-нефропатію від вовчакового нефриту [19].

За даними Насонова [4], у нирках хворих з АФС спостерігається потовщення інтими і гіперплазія середньої м'язової оболонки. У нирках можна побачити дистрофічні і некротичні зміни. Тромбоз ниркової вени при АФС може проявлятися протеїнурією, гематурією, олігурією і анурією внаслідок гострого пошкодження нирок. Найчастішим проявом тромбозу ниркової артерії є гіпертензія [10]. A. Smyth і співавт. (2010) виявили зв'язок між артеріальною гіпертензією і післяпологовим ураженням нирок у жінок з позитивними титрами ВА під час вагітності, і слід підкреслити, що гістопатологічні зміни у цих пацієнток, виявлені в зразках біопсії нирки, були характерні для тромботичної мікроангіопатії [20].

Гістологічні зміни нирок тварин із експериментальним AФC, яким вводили L-аргінін, проявляли-

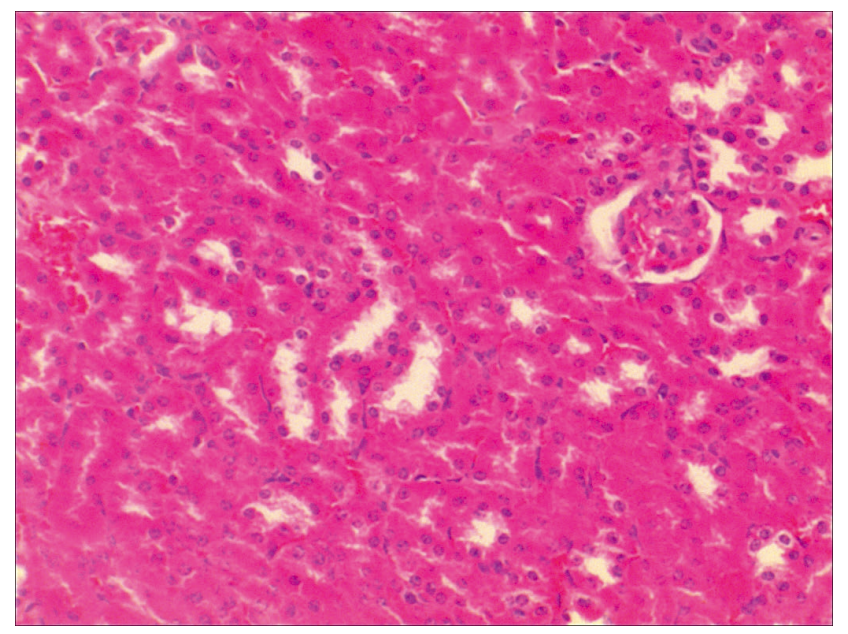

Рис. 3. Мікроскопічний стан кіркової речовини нирки миші лінії BALB/с за умов АФС та корекції L-аргініном. Ниркові тільця з помірно кровонаповненими судинними клубочками, малозмінені канальці нефрона. Забарвлення гематоксиліном та еозином. $\times 200$.

ся зменшенням кровонаповнення судин органа із збереженням цілісності судинної стінки. Формені елементи крові виявляються переважно у венозному руслі строми та помірно в артеріолах і гемокапілярах судинних клубочків. За умов застосування L-аргініну зменшується кількість гіпер- і гіпотрофованих ниркових тілець, вони переважно звичайних розмірів без проявів посиленого кровонаповнення, із збереженим епітелієм внутрішнього і зовнішнього листків капсули Шумлянського-Боумена (рис. 3).

Спостерігаються незначні зміни проксимальних канальців, нефроцити, що їх вистилають, помірно набряклі, цитоплазма частини епітеліоцитів зерниста. Ядра без явищ гіперхромії, помірно базофільні, рідко виявляється десквамація клітин у просвіт канальця. Епітеліоцити дистального відділу нефрона без виразних деструктивних змін.

Мікроскопічні зміни нирок тварин із модельованим АФС, яким вводили аміногуанідин, проявляються розширенням і кровонаповненням багатьох судин, переважно дрібних артерій кіркової речовини органа. Визначаються помірно і подекуди значно кровонаповнені капіляри перитубулярної сітки та деяких кровоносних капілярів судинних клубочків. Виявляються деформовані, зміненої форми ниркові тільця, однак меншою мірою, порівняно із нирками тварин 2 експериментальної групи. Відмічаються також нечисленні збільшені в розмірах гіпертрофовані та атрофовані ниркові тільця. Реорганізація проксимальних та дистальних канальців проявляється помірним розширенням просвітів, незначним набряком цитоплазми епітеліоцитів, подекуди із її вакуолізацією. Більшість ядер клітин помірно базофільні, еухроматинові (рис. 4).

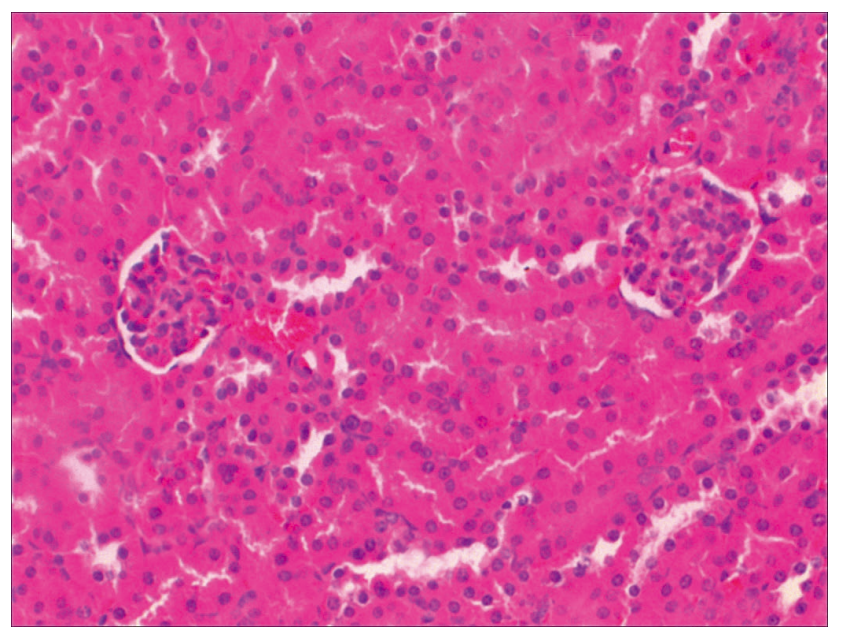

Рис. 4. Гістологічні зміни нирки миші лінії BALB/с за умов АФС та корекції аміногуанідином. Помірно кровонаповнені дрібні судини, змінені ниркові тільця і канальці нефронів. Забарвлення гематоксиліном та еозином. $\times 200$. 
Огляди літератури, оригінальні дослідження, погляд на

В 5 експериментальній групі за умов поєднаного застосування L-аргініну та аміногуанідину у нирках мишей з АФС виявляються найменші зміни деструктивного характеру, наявна відносна нормалізація судинного компонента органа, залишаються кровонаповненими тільки міжчасткові та міжчасточкові вени. Судинні клубочки помірно кровонаповнені, просвіти капсул незначно розширені. Цитоплазма епітеліоцитів канальців нефрона без ознак набряку, з чітко контурованими мембранами плазмолеми, містить округлі слабобазофільні,

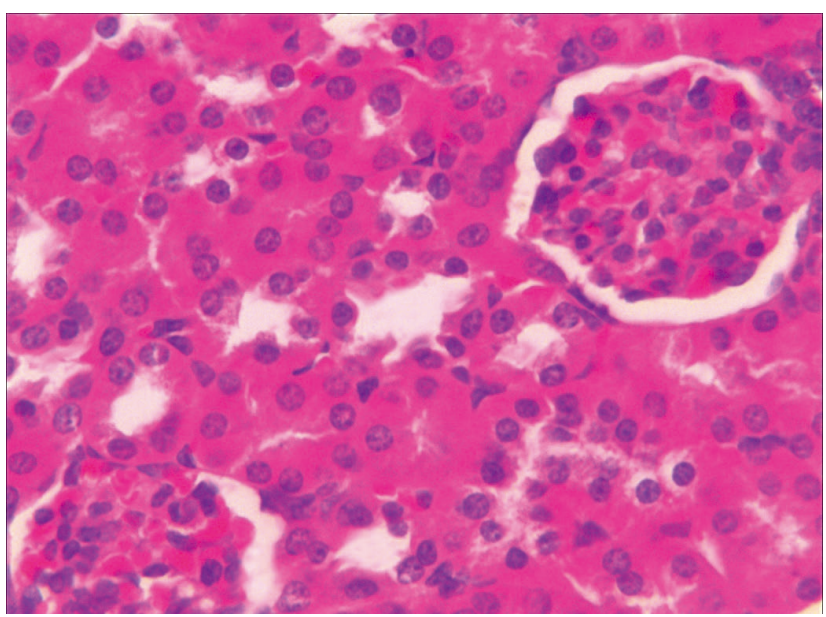

Рис. 5. Мікроскопічний стан кіркової речовини нирки миші лінії BALB/с за умов AФC та корекції L-аргініном та аміногуанідином. Ниркове тільце та звивисті канальці нефронів без ознак пошкодження. Забарвлення гематоксиліном та еозином. $\times 400$.

\section{ЛІТЕРАТУРА}

1. Granakopoulos B. The pathogenesis of the antiphospholipid syndrome / B. Granakopoulos, S. Krilis // The New England Journal of Medicine. - 2013. - Vol. 368. P. $1033-1044$.

2. Козловская Н. Л. Сосудистое поражение почек при антифосфолипидном синдроме (обзор литературы) / Н. Л. Козловская // Нефрология и диализ. - 2006. № 3. - С. 206-216.

3. Tektonidou M. G. Antiphospholipid syndrome (APS) nephropathy in catastrophic, primary, and systemic lupus erythematosus-related APS / M. G. Tektonidou, F. Sotsiou, H. M. Moutsopoulos // J. Rheumatol. -2008. - Vol. 35 (10). P. 1983-1988.

4. Насонов Е. Л. Антифосфолипидный синдром / Е. Л. Насонов. - М. : Литтерра, 2004. - 440 с.

5. Mechanisms of endothelial dysfunction in antiphospholipid syndrome: Association with clinical manifestations / M. Velásquez, M. Rojas, V. M. Abrahams [et al.] // Front. Physiol. - 2018. - Vol. 21 (9). - P. 1840. DOI: $10.3389 /$ fphys.2018.01840.

6. Піліпонова В. В. Роль ендотеліальної дисфункції нирок в патогенезі захворювань та їх ускладнень (огляд літератури) / В. В. Піліпонова, еухроматинові ядра. Просвіти канальців, особливо дистальних, чіткі, не розширені. Структурна організація збірних канальців і трубочок також без видимих змін (рис. 5).

Висновки. 1. За умов експериментального антифосфоліпідного синдрому в нирці відбуваються істотні судинні порушення, які призводять до значних деструктивних змін нефронів. Порушується загальна гемодинаміка органа та мікроциркуляція у ниркових тільцях і перитубулярній кровоносній сітці, розвиваються деструктивні і дистрофічні зміни епітеліоцитів проксимальних і дистальних канальців.

L-аргінін та аміногуанідин, особливо за умов їх комбінованого введення, зменшують патологічні зміни компонентів нефрона, порівняно з групою тварин із АФС, що проявляється відновленням мікроциркуляції в органі, покращенням структури ниркових тілець та епітеліоцитів канальців нефрона, що свідчить про відносну нормалізацію фаз процесу сечоутворення у нирках експериментальних тварин.

Перспективи подальших досліджень. Отримані нами результати досліджень структури нирок при антифосфоліпідному синдромі та позитивних змін в органі, які виникають під впливом модуляторів синтезу оксиду азоту, $\epsilon$ підґрунтям для подальшого поглибленого вивчення можливостей застосування цих засобів для корекції ураження нирок при антифосфоліпідному синдромі.

В. А. Слободянюк // Здобутки клінічної і експериментальної медицини. - 2019. - № 3. - С. 32-38. DOI: 10.11603/1811-2471.2019. v.i3.10503

7. Clinical relevance of nitric oxide metabolites and nitrative stress in thrombotic primary antiphospholipid syndrome / P. R. Ames, J. R. Batuca, A. Ciampa [et al.] // J. Rheumatol. - 2010. - Vol. 37 (12). - P. 2523-2530.

8. Wijetilleka S. Novel insights into pathogenesis, diagnosis and treatment of antiphospholipid syndrome / S. Wijetilleka, T. Scoble, M. Khamashta // Curr. Opin. Rheumatol. - 2012. - Vol. 24 (5). - P. 473-481.

9. Dual effect of nitric oxide on uterine prostaglandin synthesis in a murine model of preterm labour / M. Cella, M. G. Farina, A. P. Dominguez [et al.] // Br. J. Pharmacol. 2010. - Vol. 161 (4). - P. 844-855.

10. Головач И. Ю. Поражение почек на фоне антифосфолипидного синдрома / И. Ю. Головач, Е. Д. Егудина, Д. Г. Рекалов // Pocki. - 2019. - Vol. 8 (3). - P. 161-173. DOI: 10.22141/2307-1257.8.3.2019.176455

11. Острякова Е. В. Антифосфолипидный синдром и система фибринолиза / Е. В. Острякова, Л. И. Патрушев, Т. М. Решетняк // Научно-практическая ревматология. - 2011. - № 6. - С. 57-64. 
Огляди літератури, оригінальні дослідження, погляд на проблему, випадок з практики, короткі повідомлення

12. Krone K. A. Impaired fibrinolysis in the antiphospholipid syndrome / K. A. Krone, K. L. Allen, K. R. McCrae // Curr. Rheumatol. Rep. - 2010. - Vol. 12 (1). - P. 53-57.

13. The role of beta-2-glycoprotein I in health and disease associating structure with function: more than just APS / T. McDonnell, C. Wincup, I. Buchholz [et al.] // Blood Reviews. - 2019. - Vol. 33. - P. 100610.

14. Gao R. Beta2-glycoprotein I expression in lupus nephritis patients with antiphospholipid-associated nephropathy / R. Gao, W. Yu, Y. Wen [et al.] // J. Rheumatol. - 2016. - Vol. 43. - P. 2026-2032.

15. Морфологічний стан матки та плаценти при експериментальному моделюванні гестаційного антифосфоліпідного синдрому на мишах / Г. В. Зайченко, Ю. Б. Лар'яновська, Т. В. Деєва [та ін.] // Український медичний альманах. - 2011. - Т. 14, № 4. - С. 136-141.

16. Горальський Л. П. Основи гістологічної техніки і морфофункціональні методи досліджень у нормі та при патології / Л. П. Горальський, В. Т. Хомич, О. І. Кононський. - Житомир: Полісся, 2011. - 288 с.

\section{REFERENCES}

1. Granakopoulos, B., \& Krilis, S. (2013). The pathogenesis of the antiphospholipid syndrome. The New England Journal of Medicine, 368, 1033-1044.

2. Kozlovskaya, N.L. (2006). Sosudistoye porazheniye pochek pri antifosfolipidnom sindrome (Obzor literatury) [Vascular damage to the kidneys with antiphospholipid syndrome (review)]. Nefrologiya i dializ - Nephrology and Dialysis, 8(3), 206-216 [in Russian].

3. Tektonidou, M.G., Sotsiou, F., \& Moutsopoulos, H.M. (2008). Antiphospholipid syndrome (APS) nephropathy in catastrophic, primary, and systemic lupus erythematosusrelated APS. J. Rheumatol., 35 (10), 1983-1988.

4. Nasonov, E.L. Antyfosfolipydnyy syndrom [Antiphospholipid syndrome]. Moscow: Litterra [in Russian].

5. Velásquez, M., Rojas, M., Abrahams, V. M., Escudero, C., \& Cadavid, A. P. (2018). Mechanisms of endothelial dysfunction in antiphospholipid syndrome: Association with clinical manifestations. Front. Physiol., 21 (9), 1840. doi: 10.3389/fphys.2018.01840

6. Piliponova, V.V., \& Slobodianiuk, V.A. (2019). Rol endotelialnoi dysfunktsii nyrok v patohenezi zakhvoriuvan ta yikh uskladnen (Ohliad literatury) [The role of endothelial dysfunction in the pathogenesis of diseases and their complications (Review)]. Zdobutky klinichnoi i eksperymentalnoi medytsyny - Achievements of Clinical and Experimental Medicine,3,32-38.doi10.11603/1811-2471.2019.v.i3.10503 [in Ukrainian].

7. Ames, P.R., Batuca, J.R., Ciampa, A., lannaccone, L., \& Alves, J.D. (2010). Clinical relevance of nitric oxide metabolites and nitrative stress in thrombotic primary antiphospholipid syndrome. J. Rheumatol., 37 (12), 2523-2530.

8. Wijetilleka, S., Scoble, T., \& Khamashta, M. (2012). Novel insights into pathogenesis, diagnosis and treatment of antiphospholipid syndrome. Curr. Opin. Rheumatol., 24 (5), 473-481.

9. Cella, M., Farina, M.G., Dominguez, A.P., Girolamo, R.D., Ribeiro, M.L., \& Franchi, A.M. (2010). Dual effect
17. Antiphospholipid antibody profiles in lupus nephritis with glomerular microthrombosis: a prospective study of 124 cases / H. Zheng, Y. Chen, W. Ao [et al.] // Arthritis Res. Ther. - 2009. - Vol. 11 (3). - P. 93. DOI: 10.1186/ar2736

18. Histological antiphospholipid-associated nephropathy versus lupus nephritis in patients with systemic lupus erythematosus: an observational cross-sectional study with longitudinal follow-up / J. Gerhardsson, B. Sundelin, A. Zickert [et al.] // Arthritis Res Ther. - 2015. - Vol. 17. P. 109. DOI: 10.1186/s13075-015-0614-5.

19. Renal involvement in antiphospholipid syndrome / F. V. A. de Azevedo, D. G. Maia, J. F. de Carvalho [et al.] // Rheumatol. Int. - 2018. - Vol. 38 (10). - P. 1777-1789. DOI: $10.1007 / \mathrm{s} 00296-018-4040-2$

20. A systematic review and meta-analysis of pregnancy outcomes in patients with systemic lupus erythematosus and lupus nephritis / A. Smyth, G. H. Oliveira, B. D. Lahr [et al.] // Clin. J. Am. Soc. Nephrol. - 2010. - Vol. 5 (11). P. 2060-2068. DOI: 10.2215/CJN.00240110

of nitric oxide on uterine prostaglandin synthesis in a murine model of preterm labour. Br. J. Pharmacol., 161 (4), 844-855.

10. Golovach, I.Yu., Yegudina, Ye.D., \& Rekalov, D.G. (2019). Porazheniye pochek na fone antifosfolipidnogo sindroma [Kidney damage on the background of antiphospholipid syndrome]. Pochki - Kidneys, 8 (3), 161-173. doi: 10.22141/2307-1257.8.3.2019.176455 [in Russian].

11. Ostryakova, Ye.V., Patrushev, L.I., \& Reshetnyak, T.M. (2011). Antifosfolipidnyy sindrom i sistema fibrinoliza [Antiphospholipid syndrome and fibrinolysis system]. Nauchno-prakticheskaya revmatologiya - Scientific and Practical Rheumatology, 6, 57-64 [in Russian].

12. Krone, K.A., Allen, K.L., \& McCrae, K.R. (2010). Impaired fibrinolysis in the antiphospholipid syndrome. Curr. Rheumatol. Rep., 12 (1), 53-57.

13. McDonnell, T., Wincup, C., Buchholz, I., Pericleousc, C., Giles, I., \& Ripoll, V. (2019). The role of beta-2-glycoprotein $\mathrm{I}$ in health and disease associating structure with function: more than just APS. Blood Reviews, 33, 100610.

14. Gao, R., Yu, W., Wen, Y., \& Li, H. (2016) Beta2-glycoprotein I expression in lupus nephritis patients with antiphospholipid-associated nephropathy. J. Rheumatol., 43, 2026-2032.

15. Zaichenko, H.V., Larianovska, Yu.B., Deieva, T.V., Shevchenko, O.I., Starokozhko, V.Yu., Kudina, O.V., \& Sak, I. Yu. (2011). Morfolohichnyi stan matky ta platsenty pry eksperymentalnomu modeliuvanni hestatsiinoho antyfosfolipidnoho syndromu na myshakh [Morphological state of the uterus and placenta in experimental modeling of gestational antiphospholipid syndrome in mice]. Ukrainskyi medychnyi almanakh - Ukrainian Medical Almanac, 14 (4), 136-141 [in Ukrainian].

16. Horalskyi, L.P., Khomych, V.T., \& Kononskyi, O.I. (2011). Osnovy histolohichnoi tekhniky i morfofunktsionalni metody doslidzhen u normi ta pry patolohii [Fundamentals 
Огляди літератури, оригінальні дослідження, погляд на проблему, випадок з практики, короткі повідомлення of histological technique and morphofunctional methods of research in norm and in pathology]. Zhytomyr: Polissia [in Ukrainian].

17. Zheng, H., Chen, Y., Ao, W., Yan, Shen, Xiao-Wei, Chen, Min, Dai, Xiao-dong, Wang, Yu-Cheng, Yan \& Chengde, Yang (2009). Antiphospholipid antibody profiles in lupus nephritis with glomerular microthrombosis: a prospective study of 124 cases. Arthritis Res. Ther., 11 (3), 93. doi: 10.1186/аг2736

18. Gerhardsson, J., Sundelin, B., Zickert, A., Padyukov, L., Svenungsson, E., \& Gunnarsson, I. (2015). Histological antiphospholipid-associated nephropathy versus lupus nephritis in patients with systemic lupus erythematosus:

an observational cross-sectional study with longitudinal follow-up. Arthritis Res. Ther., 17, 109. doi: 10.1186/ s13075-015-0614-5

19. de Azevedo, F.V.A., Maia, D.G., de Carvalho, J.F., \& Rodrigues C.E.M. (2018). Renal involvement in antiphospholipid syndrome. Rheumatol. Int., 38 (10), 1777-1789. doi: 10.1007/s00296-018-4040-2

20. Smyth, A., Oliveira, G.H., Lahr, B.D., Bailey, K.R., Norby, S.M., \& Garovic, V.D. (2010). A systematic review and meta-analysis of pregnancy outcomes in patients with systemic lupus erythematosus and lupus nephritis. Clin. J. Am. Soc. Nephrol., 5 (11), 2060-2068. doi: 10.2215/ CJN.00240110

\section{МОРФОЛОГИЧЕСКИЕ ИЗМЕНЕНИЯ В ПОЧКАХ ПРИ ЭКСПЕРИМЕНТАЛЬНОМ АНТИФОСФОЛИПИДНОМ СИНДРОМЕ И ПРИМЕНЕНИИ МОДУЛЯТОРОВ СИНТЕЗА ОКСИДА АЗОТА}

๑О. З. Яремчук, 3. М. Небесная, С. Б. Крамар, Е. А. Посохова

Тернопольский национальный медицинский університет имени И. Я. Горбачевского МОз Украины

РЕЗЮМЕ. Почки являются одним из основных органов-мишеней при всех клинических формах антифосфолипидного синдрома (АФС).

Цель - оценить влияние предшественника синтеза оксида азота L-аргинина и ингибитора индуцибельной NO-синтазы аминогуанидина на морфофункциональные изменения в почках при экспериментальном АФС.

Материал и методы. Исследование выполнено на мышах-самках линии BALB/c, у которых моделировали AФС. Для коррекции использовали L-аргинин (25 мг/кг) и аминогуанидин (10 мг/кг). Забор материала для микроскопических исследований проводили согласно общепринятой методике. Образцы ткани почек окрашивали гематоксилином и эозином.

Результаты. При микроскопическом исследовании почек животных с АФС обнаружены деструктивные изменения всех компонентов и нарушение мозгового и коркового кровообращения в органе. Гистологические изменения почек мишей с АФC, которым вводили L-аргинин, проявлялись уменьшением кровонаполнения сосудов с сохранением целостности сосудистой стенки. Микроскопические изменения почек животных с АФС, которым вводили аминогуанидин, характеризовались расширением и кровонаполнением сосудов преимущественно мелких артерий коркового вещества. При введении L-аргинина и аминогуанидина при АФС в почках обнаружено восстановление сосудистого компонента органа, оставались кровонаполненными только междолевые и междольковые вены.

Выводы. В почках при АФС происходят сосудистые нарушения, которые ведут к деструктивным изменениям нефронов. Применение модуляторов синтеза оксида азота (L-аргинина и аминогуанидина), отдельно и, особенно, при их комбинированном введении, сопровождается уменьшением патологических изменений компонентов нефрона при АФС у мышей линии BALB/c.

КЛЮЧЕВЫЕ СЛОВА: антифосфолипиднЫй Синдром; почки; L-аргинин; аминогуанидин.

\section{MORPHOLOGICAL CHANGES IN THE KIDNEY IN EXPERIMENTAL ANTIPHOSPHOLIPID SYNDROME: EFFECTS OF NITRIC OXIDE SYNTHESIS MODULATORS}

\section{O. Z. Yaremchuk, Z. M. Nebesna, S. B. Kramar, K. A. Posokhova \\ I. Horbachevsky Ternopil National Medical University}

SUMMARY. The kidneys are one of the main target organs in all clinical forms of antiphospholipid syndrome (APS). The aim - to assess the effect of L-arginine, the precursor of nitric oxide synthesis, and NO synthase, the inhibitor of inducible aminoguanidine, on morphofunctional changes in the kidneys in experimental APS.

Material and Methods. The BALB/c female mice modeled with APS were used in the study. L-arginine $(25 \mathrm{mg} / \mathrm{kg})$ and aminoguanidine $(10 \mathrm{mg} / \mathrm{kg}$ ) were used for correction. The sampling of the material for microscopic examination was performed according to conventional methods. Kidney tissue samples were stained with hematoxylin and eosin.

Results and Discussion. Microscopic studies of the kidneys of the animals with APS revealed destructive changes in all components and impaired cerebral and circulatory organ flow. Histologic changes of kidneys of the animals modeled 
Огляди літератури, оригінальні дослідження, погляд на проблему, випадок з практики, короткі повідомлення with APS, which were administered with L-arginine, were manifested by a decrease in blood supply of organ vessels maintaining the integrity of vascular wall. Microscopic changes of kidneys of the animals with APS administered with aminoguanidine were manifested by enlargement and blood filling of many vessels of predominantly small arteries of the cortical substance.

With the introduction of L-arginine and aminoguanidine, a relative normalization of the vascular component of the organ was revealed in the kidneys of the animals with APS; only the interparticle and interstitial veins were blood filled.

Conclusions. Vascular disorders occur in the kidney in cases of APS that cause significant destructive changes of the nephrons. The application of modulators of nitric oxide synthesis (L-arginine and aminoguanidine), separately and especially when combined, leads to reduction of pathological changes in nephron components in the presence of APS in the BALB/c mice.

KEY WORDS: antiphospholipid syndrome; kidney; L-arginine; aminoguanidine.

Отримано 19.02 .2020 